\title{
SLOW AND FAST DRYING IN SEEDS OF Ocotea puberula (Rich.) Ness ${ }^{1}$
}

\author{
Dalciana Vicente Tanaka ${ }^{2 *}$, Luciana Magda de Oliveira ${ }^{3}$, Patrícia Paloma Liesch ${ }^{4}$ and Mara Luana Engel ${ }^{4}$
}

\footnotetext{
${ }^{1}$ Received on 08.08.2014 accepted for publication on 25.10.2016.

${ }^{2}$ Universidade do Estado de Santa Catarina, Programa de Pós-Graduação em Engenharia Florestal, Lages, Santa Catarina, Brasil.E-mail: <dalciana@gmail.com>.

${ }^{3}$ Universidade do Estado de Santa Catarina, Departamento de Engenharia Florestal, Lages, Santa Catarina, Brasil. E-mail: <a21mo@cav.udesc.br>.

${ }^{4}$ Universidade do Estado de Santa Catarina, Graduada em Engenharia Florestal, Lages, Santa Catarina, Brasil. E-mail: <patricialiesch@hotmail.com> and <maraluana_pzo@hotmail.com>.

*Corresponding author.
}

\begin{abstract}
The objective of this work was to evaluate the influence of types of drying on seeds' quality, as recalcitrant, Ocotea puberula and determine their degree of critical humidity and lethal degree. Seeds harvested in Brunópolis, SC, with an initial moisture content of $38 \%$, were dried to $18 \%$, with gradients of $2 \%$; using the equation of target weight to ensure that gradient in the stove $(35 \mathrm{oC})$ and in a desiccator with silica gel $(25 \mathrm{oC})$. After drying, the seeds were evaluated for water content, percentage and germination speed index (GSI), tetrazolium and T50. It was observed that up to $32 \%$ water content did not change in seed quality, regardless of the type of drying and verified significant loss of germination after this value. We conclude that the type of drying does not affect the quality of the seed; however, because it is a recalcitrant seed, reducing the water content below $32 \%$ decreased germination, and its degree of critical humidity and seeds with $22 \%$ moisture content had no germination in this study is the degree of lethal humidity of this species.
\end{abstract}

Key-words: Canela-guaicá; Recalcitrant seed; Water content.

\section{SECAGEM LENTA E RÁPIDA EM SEMENTES DE Ocotea puberula (Rich.) NesS}

\begin{abstract}
RESUMO - Objetivou-se avaliar a influência de tipos de secagem na qualidade de sementes, consideradas recalcitrantes, de Ocotea puberula e determinar o seu grau de umidade crítico e grau letal. Sementes colhidas em Brunópolis, SC, com teor de água inicial de 38\%, foram secas até $18 \%$, com gradientes de 2\%; utilizando a equação de peso alvo para garantir este gradiente, em estufa $(35 \mathrm{oC})$ e em dessecador com sílica-gel (25oC). Após cada secagem, as sementes foram avaliadas quanto ao teor de água, porcentagem e velocidade (IVG) de germinação, T50 e tetrazólio. Foi observado que até 32\% de teor de água não houve alteração na qualidade das sementes, independente do tipo de secagem, sendo verificada significativa perda de germinação após esse valor. Conclui-se que o tipo de secagem não influencia na qualidade dessas sementes; porém, por tratar-se de uma semente recalcitrante, a redução do teor de água abaixo de 32\% prejudica a germinação, sendo seu grau de umidade crítico e sementes com $22 \%$ de teor de água não tiveram germinação, sendo neste estudo o grau de umidade letal desta espécie.
\end{abstract}

Palavras-chave: Canela-guaicá; Semente recalcitrante; Teor de água. 


\section{INTRODUCTION}

Seeds are commonly classified according to their longevity, and tolerance to both desiccation and low temperatures, which can be either orthodox (tolerant) or recalcitrant (intolerant) (ROBERTS, 1973). However, Ellis et al. (1990) defined a third category as the intermediates, which are relatively desiccant-tolerant. Nonetheless, these seeds do not withstand low temperatures storage as the orthodox tolerated levels.

Recalcitrant seeds conservation poses a challenge due to a peculiar characteristic of these seeds that can neither lose large amounts of water nor being stored more than few weeks or months (MARCOS FILHO, 2005). At dispersion moment, these seeds denotes elevated water content, and are metabolically active. Moreover, in several cases these seeds are initiating germination (KERMODE; FICH-SAVAGE, 2002).

Farrant et al. (1985) suggested that there are different types of recalcitrant seeds: minimally, moderately and highly recalcitrant, and that their characteristics are partially related with the habitat. In minimally recalcitrant species, the seeds can withstand to the loss of higher moisture levels and may remain viable for longer periods. These species have a subtropical distribution; therefore, those also tolerate lower temperatures. The Quercus sp., Araucaria hunsteinii and Podocarpus henkelii are example of that.

Moderately recalcitrant seeds might tolerate the loss of moderate water contents and present sensitiveness to inferior temperatures. Several of these species have a tropical distribution, for instance, the Theobroma cacao and Hevea brasiliensis. In contrast, the highly recalcitrant bears a loss of minimum water content and are not able to survive under lower temperature. These types are usually dwelling in tropical forests, wetlands and mangroves, such as Avicennia marina.

In recalcitrant seeds desiccation, several indexes should be considered, such as the safety humidity degree, the critical moisture degree and finally degree of lethal moisture. These indexes varies depending on the selected specie. The safety moisture degree corresponds to a level that could be reached through drying processes without damaging seeds viability (HONG, ELLIS, 1992); the critical humidity degree refers to a value at which the beginning of viability loss is detected (ANDRADE; CUNHA, 1996). Finally, the lethal moisture degree represents the point at which every seeds loses viability (HONG; ELLIS, 1992).

Drying processes may influence the response of recalcitrant seeds to desiccation (WESLEY-SMITH et al., 2001; JOSÉ et al., 2011).Certain authors argue that rapid seeds' drying process is an effective reducer of damages by viability loss (FARRANT et al., 1985; BERJAK et al., 1990; PRITCHARD, 1991; PAMMENTER et al., 1998). On the other hand, slow drying may promote enhanced desiccation tolerance due to the time, which is responsible to induction and operation of protection mechanisms for seeds. (SILVA et al., 2007).

Ekebergia capensis recalcitrant seeds, for example, when rapidly dried maintained viability at a reasonably low water content $(0.7 / \mathrm{g}$ of water per gram of dry weight); while slow drying led to complete viability loss (PAMMENTER et al., 1998). According to Magistrali et al. (2013), slow drying increased desiccation capacity and storage tolerance in studies with Genipa americana seeds. Furthermore, in coffee seeds (Coffea anefora), fast drying caused a greater reduction in physiologic quality compared to slow and intermediate drying (ROSA et al., 2005). Ocotea puberula specie have their seeds classified as recalcitrant as pointed out by Mori et al. (2012). Therefore, based on what was exposed, the aim of this study was to verify the influence of two drying processes; laboratory stove (fast drying), and silica gel (slow drying) on these seeds quality and determine the critical and lethal moisture degrees.

\section{MATERIALAND METHODS}

Ocotea puberula seeds were collected at Brunópolis, SC, located at latitude $27^{\circ} 18^{\prime} 21^{\prime \prime} \mathrm{S}$, longitude $50^{\circ} 52^{\prime} 06^{\prime \prime}$, and altitude of $843 \mathrm{~m}$. This city presents an average temperature of $19^{\circ} \mathrm{C}$ and annual precipitation mean of $1.733 \mathrm{~mm}$ (GOVERNO DO ESTADO DE SANTA CATARINA, 2013; CLIMATE-DATA, 2014)

The seeds were collected from black-bluish pigmented fruits considered ripe in five matrixes, with the aid of pruning tools. Pulp removal was performed manually with the aid of sieves and running water. The water excess was removed with paper towel. Water content determination was carried out through laboratory stove method, where seeds were submitted to a temperature of $103^{\circ} \mathrm{C} \pm 2^{\circ} \mathrm{C}$ for 24 hours. This test was performed in duplicate containing ten seeds each 
replicate. The outcomes were exposed in percentage, based on seeds moisture weight according to Rules for Testing Seeds (BRASIL, 2009).

For seeds drying, 10 moisture gradients were established starting with $38 \%$ (initial humidity's lot), and having $18 \%$ as the last gradient, varying from 2 to $2 \%$. The moisture gradients were obtained by weight difference between initial and target weight, according to Hong; Ellis (1996) following formula [1] described below:

[1] Target weight $=\left[\left(100-\mathrm{U}_{\text {initial }}\right) /\left(100-\mathrm{U}_{\text {target }}\right)\right] \times$ Initial sample weight

After each seed had reached the pre-established humidity gradient, the water content was determined by laboratory stove method in order to measure the obtained outcomes with the aforementioned formula.

For slow drying, 11 samples of 160 seeds each were weighed and placed in 11 "mesh type" bags, which allow the passage of air and water. The bags were randomly dispose in a desiccator with silica gel under constant temperature of $25^{\circ} \mathrm{C}$. On the other hand, although 11 samples of 160 seeds each were also weighed for fast drying, these were placed in aluminum screens to facilitate water removal. The screens were indiscriminately arranged in a forced ventilation stove with a constant temperature of $35^{\circ} \mathrm{C}$. The samples of both drying methods were regularly weighed until reaching the target weight. Then, the samples were conditioned to moisture determination, viability and vigor tests.

Seeds physiological quality was determined by germination tests (BRASIL, 2009); Germination Speed Index (GSI) as suggested by Maguire (1962) formula; Mean Germination Time ( $\mathrm{T}$ 50) reported by Copeland; McDonald (1985); and Tetrazolium (Tz), regarding Kalil Filho (2008) methodology.

For GSI and T50 germination tests, seeds were conditioned on germitest paper, which were previously moistened with two times the weight of the paper. Then, the species were placed to germinate in a Mangelsdorf germination chamber with temperature of $30^{\circ} \mathrm{C}$ within a constant light. For each moisture gradient, four repetitions of twenty seeds were utilized, and the integument was manually removed. The results were expressed in regular plants percentage, according to Brazil (2009).
For the tetrazolium test, 60 seeds were divided in four replicates. In adittion, those were longitudinally sectioned through embryonic axis center with the aid of a scalpel. Then, these seeds were immersed in the solution of 2,3,5- triphenyltetrazolium chloride ( $\mathrm{pH} 6.5$ -7.0 ) in the concentration of $0.5 \%$ for one hour. Moreover, to support the picturing of every seed detail, two table loupes with magnifying glass were utilized. The criteria analyses were: 1 - viable seed (reddish color), 2- unviable seeds (colorless). Furthermore, the results were expressed in percentage of viable seeds.

The experiments were assembled in a completely randomized design, and data were tested for normality and submitted to variance analysis. The germination data and T 50 expressed as percentages were shown to be non-homogeneous by the Shapiro-Wilk test. Thus, these tests were transformed into arco seno $\sqrt{x / 100}$, and the GSI data were converted into $\sqrt{\mathrm{x}+0,5}$, according to methodology suggested by Santana; Ranal (2004). The means were compared using Tukey test at 5\% probability to prove statistical significance, and the analysis were performed by ASSISTAT ${ }^{\circledR}$ statistical program.

\section{RESULTS}

Seeds submitted to drying methods in both laboratory stove and silica gel took 240 hours ( 10 days) and 602 hours (25 days) respectively to achieve the last drying point (18\%). For this reason, the stove method was classified as fast drying, while the silica gel was classified as slow drying.

The determination of approximated pre-established water levels in this study was possible due to target weight formula (HONG; ELLIS, 1996). The levels were similar to those verified by laboratory stove ascertainment (Table 1).

Ocotea puberula seeds germination varied during the drying process. Initial germination speed with newly harvested seeds was $76 \%$, which remained until the moisture of $36 \%$ in the slow drying. However, germination potential decreased in fast drying to $62 \%$. It was observed that germination percentage increased with moisture reduction at $34 \%$ and $32 \%$ in the fast drying decreasing until reaching zero at $22 \%$ of water content for both drying types (Graphic 1)

Regarding vigor (GSI and T50), diminutions were observed from $32 \%$ moisture levels regardless the

Revista Árvore, Viçosa-MG, v.40, n.6, p.1059-1065, 2016

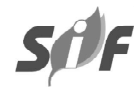


Table 1 - Drying Hours (HS), gradient preset humidity (GPE) and met (U\%) through use of the methodology of the target weight, in seeds of Ocotea puberula.

Tabela 1 - Horas de secagem (HS), gradiente de umidade pré-estabelecido (GPE) e atingidos (U\%), por meio da utilização de metodologia do peso alvo, em sementes de Ocotea puberula.

\begin{tabular}{ccccccc}
\hline \multicolumn{3}{c}{ Slow Drying } & & \multicolumn{3}{c}{ Fast Drying } \\
\cline { 1 - 3 } \cline { 5 - 6 } HS & GPE & U\% & & HS & GPE & U\% \\
\hline 0 & 38 & 37.79 & & 38 & 38.28 \\
5 & 36 & 36.39 & & 36 & 36.34 \\
45 & 34 & 33.71 & & 5 & 34 & 34.52 \\
98 & 32 & 32.13 & & 28 & 32 & 32.11 \\
214 & 30 & 29.69 & & 50 & 30 & 30.37 \\
483 & 28 & 29.31 & 69 & 28 & 28.74 \\
483 & 26 & 26.63 & & 100 & 26 & 26.99 \\
507 & 24 & 22.53 & & 148 & 24 & 24.77 \\
554 & 22 & 23.65 & 169 & 22 & 21.88 \\
577 & 20 & 20.79 & & 171 & 20 & 20.97 \\
602 & 18 & 19.45 & 240 & 18 & 18.99 \\
\hline
\end{tabular}

Source: Elaborated by the author.

Fonte: Produção do próprio autor.

Source: Elaborated by the author.

Fonte: Produção do próprio autor.

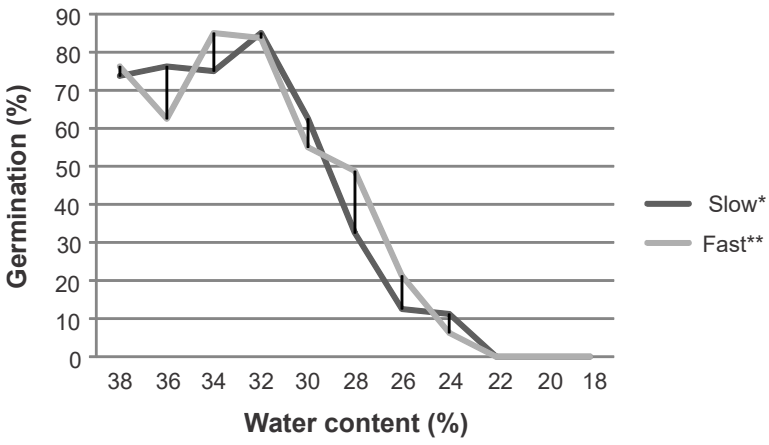

Figure 1 - Germination of Ocotea puberula, undergoing slow and fast drying.

*Linear regression Slow Drying: $y=20,774+0,212 x\left(R^{2}=0,823\right)$.

$* *$ Linear regression Fast Drying: $\mathrm{y}=20,484+0,218 \mathrm{x}\left(\mathrm{R}^{2}=0,835\right)$.

Figura 1 - Germinação de sementes de Ocotea puberula, submetidas à secagem lenta e rápida.

*Regressão linear Sec. Lenta: $y=20,774+0,212 x\left(R^{2}=0,823\right)$.

**Regressão linear Sec. Rápida: y=20,484+0,218x $\left(R^{2}=0,835\right)$.

drying type. These indexes decay until reaching zero in the critical humidity degree (Graphic 2 and 3).

The majority of seeds that could not germinate were at a dormant state until $32 \%$ of water content. Even though, these seeds imbibed water, there was none radicle protrusion below $32 \%$ of water content. Furthermore, the non-germinated seeds were
Source: Elaborated by the author.

Fonte: Produção do próprio autor.

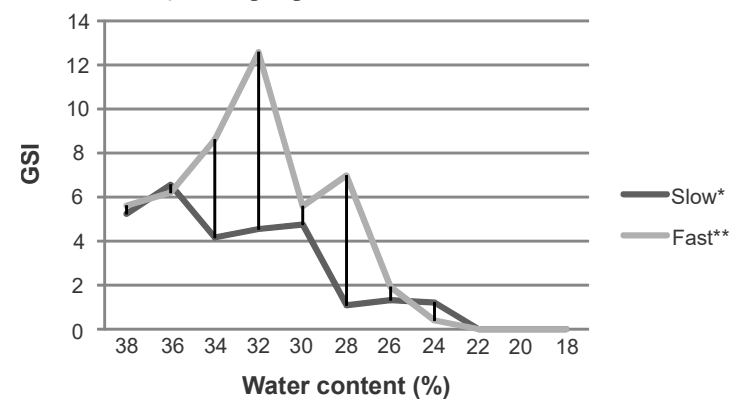

Figure 2 - Germination Speed Index (GSI) of seeds of Ocotea puberula, undergoing slow and fast drying.

* Linear regression Slow Drying: $\mathrm{y}=12,641+15,332 \mathrm{x}\left(\mathrm{R}^{2}=0,854\right)$.

** Linear regression Fast Drying: $\mathrm{y}=13,129+14,338 \mathrm{x}\left(\mathrm{R}^{2}=0,804\right)$.

Figura 2 - Indice de Velocidade de Germinação (IVG) de sementes de Ocotea puberula, submetidas à secagem lenta e rápida.

*Regressão linear Sec. Lenta: $y=12,641+15,332 x\left(R^{2}=0,854\right)$.

**Regressão linear Sec. Rápida: $y=13,129+14,338 x\left(R^{2}=0,804\right)$.

Source: Elaborated by the author

Fonte: Produção do próprio autor.

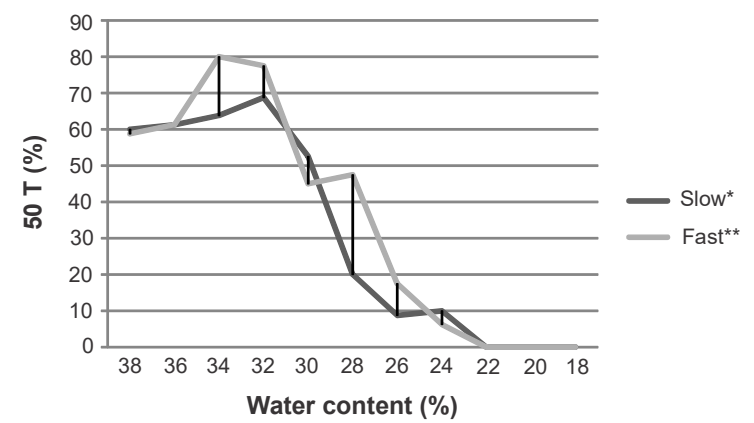

Figure 3-50 T (\%) of seeds of Ocotea puberula, subjected to slow and fast drying.

* Linear regression Slow Drying: $\mathrm{y}=20,709+0,253 \mathrm{x}\left(\mathrm{R}^{2}=0,835\right)$.

** Linear regression Fast Drying: $\mathrm{y}=20,709+0,229 \mathrm{x}\left(\mathrm{R}^{2}=0,793\right)$.

Figura 3- T 50 (\%) de sementes de Ocotea puberula, submetidas a secagem lenta e rápida.

*Regressão linear Sec. Lenta: $y=20,709+0,253 x\left(R^{2}=0,835\right)$.

**Regressão linear Sec. Rápida: $y=20,709+0,229 x\left(R^{2}=0,793\right)$.

apparently dead when the conditions were below $32 \%$ of water content denoting a dark embryo (data not shown).

Regarding tetrazolium test, more elevated values were verified than those obtained in germination test. For instance, there was none observable seeds germination at $22 \%$ of water content, which was considered a lethal level for seeds. However, values superior to $45 \%$ were obtained in tetrazolium test (Graphic 4). 
Source: Elaborated by the author.

Fonte: Produção do próprio autor.

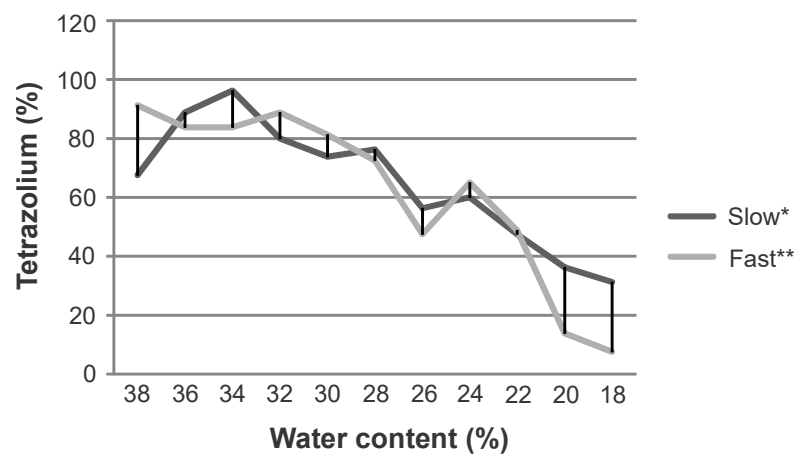

Figure 4 - Viability (tetrazolium test) of seeds of Ocotea puberula, subjected to slow and fast drying.

* Linear regression Slow Drying: $\mathrm{y}=17,968+0,166 \mathrm{x}\left(\mathrm{R}^{2}=0,359\right)$.

** Linear regression Fast Drying: $\mathrm{y}=16,128+0,191 \mathrm{x}\left(\mathrm{R}^{2}=0,763\right)$.

Figura 4 - Viabilidade (teste de tetrazólio) de sementes de Ocotea puberula, submetidas a secagem lenta e rápida.

*Regressão linear Sec. Lenta: $y=17,968+0,166 x\left(R^{2}=0,359\right)$.

**Regressão linear Sec. Rápida: $y=16,128+0,191 x\left(R^{2}=0,763\right)$.

\section{DISCUSSION}

In accordance with works developed with Averrhoa carambola (Oliveira et al., 2011), and Caesalpinia ferrea (Gnoatto; Cruz-Silva, 2011) an enhancement in seeds germination when submitted to partial drying were also noticed. It is unclear what factors intensify germination; however, certain studies suggest that normal cellular functions of freshly harvested seeds could be altered when these are dried, which might either deactivate dormancy or accelerate germination processes (BERJAK et al., 1990; PAMMENTER et al., 1998; LEPRINCE et al., 2000).

Critical moisture content found for this specie was $32 \%$, wherein values inferior to this gradient presented decreasing seeds viability until the moisture gradient of $24 \%$ reaching, there were observed $15 \%$ of germination (slow drying) and $6 \%$ of germination (fast drying). From the $22 \%$ gradient, there was none germination leading to an interpretation that this gradient is considered the lethal humidity degree. According to Hirano (2002), who worked with the same specie drying point, a sharp decline of Ocotea puberula germination initiated when the seeds reached $31.8 \%$ of moisture.

Lethals and criticals humidity degrees depend on the specie. In seeds of Cryptocarya aschersoniana, from the Lauraceae family, Tonetti (2013) it was concluded that the critical humidity degree was between 28.1 and $26.3 \%$ and the lethal moisture degree was between 21.5 and $18.1 \%$. Nonetheless, for Archantophoenix alexandrae seeds with recalcitrant behavior, the critical humidity was $24.84 \%$ according to a study performed by Andrade et al (2005).

Ocotea puberula seeds germination was statistically different in six points in relation to drying types. However, in general, both methods of drying have showed similar critical and lethal humidity points. Gemaque et $a l$. (2005) found the same outcomes in seeds of Tabebuia impetiginosa Mart Standll while Oliva et al. (2012) noticed similar results in seeds of Crambe abyssinica Hochst, and Nery (2006), encountered similarities in seeds of Calophyllum brasiliense Cambess.

In tetrazolium test, higher viability values were verified than those obtained in the germination test. The studies of Marcos Filho (2005), and Walters et al. (2005) can assist this phenomenon explanation. These researchers affirm that seeds' moisture reduction at intermediate levels of 20 and $33 \%$, range in which the majority of recalcitrant seeds can be stored, maintained considerably elevated respiration rate internally in the seeds. Moreover, the diminution until reach those levels supported the metabolisms active. However, the repair system no longer works perfectly leading to a reduction in germination potentiation of these species. According to Walters et al. (2005), seeds undergo an aging acceleration in this hydration level, which leads those to dead.

\section{CONCLUSION}

The reduction of water content below $32 \%$ harm Ocotea puberula seeds germination. Therefore, this value can be considered the critical humidity degree. Moreover, levels of water content inferior to $22 \%$ were deliberated as lethal this specie seeds, i regardless the drying method (laboratory stove or silica gel).

\section{REFERENCES}

ANDRADE, A.C.S.; CUNHA, R. Grau crítico de umidade? Informativo do Comitê Técnico de Sementes Recalcitrantes, n. 1, p.2-3, 1996.

ANDRADE, R.R.; SCHORN, L.A.; NOGUEIRA, A.C. tolerância à dessecação em sementes de

Revista Árvore, Viçosa-MG, v.40, n.6, p.1059-1065, 2016

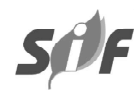


Archantophoenix alexandrae Wendl. and Drud (Palmeira real australiana). Ambiência, v.1, n.2, p.279-288, 2005.

BERJAK, P.; FARRANT, J. M.; MYCOCK, D. J.; PAMMENTER. N. W. Recalcitrant (homoiohydrous) seeds: the enigma of their desiccation-sensitivity. Seed Science and Technology, v.18, n.2, p.297-310, 1990.

BRASIL. Ministério da Agricultura e Reforma Agrária. Regras para análise de sementes. Brasília: 2009. 365p.

CLIMATE-DATA. 2014. [accessed on: mar. 24, 2014] Available at: http://pt.climate-data.org/.

COPELAND, L.O.; McDONALD, M.B. Principles of seed science and technology. 2. ed. New York: Macmillan, 1985.321p.

ELLIS, R.H.; HONG, T.D.; ROBERTS, H. An intermediate category of seed storage behaviour? Journal of Experimental Botany, v.41, n.230, p.1167-1174, 1990.

FARRANT, J.M.; BERJAK, P.; PAMMENTER, N.W. The effect of drying rate on viability retention of recalcitrant propagules of Avicena marina. South African Journal of Botany. v.51, p.32-43, 1985.

GEMAQUE, R.C.R.; DAVIDE,A.C.; DA SILVA, E. A. A.; FARIA, J. M. R. Efeito das secagens lenta e rápida em sementes de ipê-roxo (Tabebuia impetiginosa (Mart.) Standl.). Cerne, v.11, n.4, p.329-335, 2005.

GNOATTO, F.L.C.; CRUZ-SILVA, C.T.A. Superação da dormência em sementes de pau-ferro (Caesalpinia ferrea Mart. ex Tul. var. leiostachya Benth.). Cascavel, v.4, n.2, p.81-94, 2011.

GOVERNO DO ESTADO DE SANTA CATARINA. 2013. [accessed on: Jan. 16, 2014. Avaiable at: http://www.sc.gov.br.

HIRANO, E. Maturação fisiológica, tolerância à dessecação e conservação de sementes de lauráceas da mata de Araucária de Santa Catarina. Seed Science Research, v.4, p.123-126, 2002.

HONG, T.D.; ELLIS, R.H. A protocol to determine seed storage behavior. Rome: IPGRI, 1992. 62p.
HONG, T.D.; ELlis, R.H. A protocol to determine seed storage behavior. Rome: IPGRI, 1996. 62p.

JOSÉ, A.C. JOSÉ, A. C., SILVA, E. A. A., DAVIDE, A. C., MELO, A. J. S.; TOOROP, P. E. Effects of drying rate and storage time on Magnolia ovate Spreng. seed viability. Seed Science and Technology, v.39, n.2, p.425-434, 2011.

KALIL FILHO, A.N. LOPES, A. J.; RÊGO, G. M.; TOMACHITZ, A. Avaliação da Qualidade Fisiológica de Sementes de Imbuia pelo Teste do Tetrazólio (Nota científica). Pesquisa Florestal Brasileira, n.57, p.69-72, 2008.

KERMODE, A.R.; FINCH-SAVAGE, B.E. Desiccation sensitivity in orthodox and recalcitrant seeds in relation to development. In: BLACK, M.; PRITCHARD, H.W. (Ed.).

Desiccation and survival in plants: Drying without dying. Oxon: CABI Publishing, 2002. 422p.

LEPRINCE, O.; HARREN, F. J. M.; BUITINK, J.; ALBERDA, M.; HOEKSTRA, F. A. Metabolic dysfunction and unabated respiration precede loss of membrane integrity during dehydration of germinating radicles. Plant Physiology. v.122, n.2, p.597-608, 2000.

MAGISTRALI, P.R.; JOSÉ, A. C.; FARIA, J. M. R.; GASPARIN, E. Physiological behavior of Genipa americana L. seeds regarding the capacity for desiccation and storage tolerance. Journal of Seed Science. v. 35, n.4, p.495-500, 2013.

MAGUIRE, J.D. Speed of germination-aid in selection and evaluation for seedling emergence and vigor. Crop Science, v.2, p.176-177, 1962.

MARCOS FILHO, J. Fisiologia de sementes de plantas cultivadas. Piracicaba: Fealq, 2005. 495p.

MORI, E.S.; PIÑA-RODRIGUES, F. C. M.; DE FREITAS, N.P. Sementes florestais: guia para germinação de 100 espécies nativas. São Paulo: Instituto Refloresta, 2012.159p.

NERY, F.C. Aspectos da germinação, armazenamento de sementes, 
crescimento inicial e anatomia de plantas jovens de Calophyllum brasiliense Cambess. 2006. $173 \mathrm{f}$.

Dissertação (Mestrado em Fisiologia Vegetal)

- Universidade Federal de Lavras, Lavras, 2006.

OLIVA, A.C.E.; BIAGGIONI, M.A.M.; CAVARIANI, C. Efeito imediato do método de secagem na qualidade de sementes de crambe. Energia na Agricultura, v. 27, n.3, p. 16 30,2012 .

OLIVEIRA, M.T.R.; BERBERT, P. A.; CARLESSO, V.O.; THIÉBAUT, J. T.L.; VIEIRA, H.D.; PEREIRA, R.C. Efeito da secagem por convecção na germinação de sementes de carambola. Revista Brasileira de Sementes, v.33, n.2 p.233-240, 2011.

PAMMENTER, N.W.; GREGGAINS, V.; KIOKO, J.I.; WESLEY-SMITH, J.; BERJAK, P.; FINCHSAVAGE, W.E. Effects of differential drying rates on viability retention of recalcitrant seeds of Ekebergia capensis. Seed Science Research, v.8, p.463-471, 1998.

PRITCHARD, H.W. Water potential and embryonic axis viability in recalcitrant seeds of Quercus rubra. Annals of Botany, v.67, n.1, p.43-49, 1991.

ROBERTS, E.H. Storage environment and the control of viability. In: ROBERTS, E.H.

Viability of seeds. London: Syracuse University Press, 1972. p.14-58.
ROSA, S.D.V. da F.; BRANDÃO JÚNIOR, D. da S.; VON PINHO, E.V. de R.; VEIGA, A.D.; SILVA, L.H. de C. Effects of different drying rates on the physiological quality of Coffea canephora Pierre seeds. Brazilian Journal Plant Physiology, v. 17, n.2, p.199-205, 2005.

SANTANA, D.G.; RANAL, M.A. Análise da germinação: um enfoque estatístico. Brasília: Universidade de Brasília, 2004. 248p.

SILVA, P.A.; DINIZ, K. A.; OLIVEIRA, J. A.; VON PINHO, É. V.R. Análise fisiológica e ultraestrutural durante o desenvolvimento e a secagem de sementes de soja. Revista Brasileira de Sementes, v.29, n.2, p.15-22, 2007.

TONETTI, O.A.O. Alterações fisiológicas, bioquímicas e moleculares em sementes de Cryptocarya aschersoniana submetidas à secagem e ao armazenamento. 2013. 89f. Tese (Doutorado em Produção Vegetal). Lavras: UFLA, 2013.

WALTERS, C.; HILL, L.M.; WHEELER, L.J. Dying while dry: kinetics and mechanisms of deterioration in desiccated organisms.

Integrative and Comparative Biology, v.45, p.751-758, 2005.

WESLEY-SMITH, J.; PAMMENTER, N.; BERJAK, $P$. The effects of two drying rates on the desiccation tolerance of embryonic axes of recalcitrant Jackfruit (Artocarpus Heterophyllus LAMK.) seeds. Annals of Botany, v. 8, n.4, p.653-664, 2001. 